\title{
Effects of ozone on starch accumulation in Norway spruce (Picea abies)
}

\author{
Barbara Luethy-Krause and Werner Landolt \\ Swiss Federal Research Institute of Forestry, Snow and Landscape, CH-8903 Birmensdorf, Switzerland
}

Received January 10, 1990/April 17, 1990

Summary. Fumigation with $100 \mu \mathrm{g} / \mathrm{m}^{3}$ and $200 \mu \mathrm{g} / \mathrm{m}^{3}$ ozone in closed-top fumigation chambers induced starch accumulation in chloroplasts of Norway spruce. This accumulation was probably due to a partial inhibition of the starch translocation at night. The intensity of the effect was dependent on the season and the age of the needles. The accumulation was reversed in winter. It is therefore unlikely that such an effect has much significance for plant health.

Key words: Needles - Ozone - Picea abies - Starch

\section{Introduction}

Since ozone was mentioned as a possible cause for forest decline (Prinz et al. 1985) interest in ozone has been retained as it is the only pollutant found in considerable concentrations in remote areas. In order to elucidate the possible damaging effect of ozone on native trees both long-term studies on growth reduction and visible damage, and short-term studies on early changes in the biochemistry are of importance. We looked at the soluble sugars and sugar alcohols (Landolt et al. 1989) and starch, and their connection to photosynthesis and assimilate translocation.

Starch is not only an important plant metabolite, but accumulation of starch in leaves has been observed after different stresses, such as virus infection (Fink and Braun 1978), mistletoe infection (Broshot and Tinnin 1986), during certain stages of fungal infection (MacDonald and Strobel 1970), and exposure to excess of heavy metals (Samarakoon and Rauser 1979) and ozone (Hanson and Steward 1970; Tingey et al. 1976).

Accumulation of starch in the chloroplasts of spruce needles has been discussed in connection with the ,new forest decline" (,neuartige Waldschäden"). Osswald and

Offprint requests to: $\mathrm{W}$. Landolt
Elstner (1985) suggested starch accumulation in the chloroplast with following photoinhibition and photobleaching as a cause for montane yellowing, a symptom connected with ,new forest decline".

Starch concentrations in spruce needles following exposure to filtered air, ambient air, or filtered air with additional ozone were measured in different exposures during 1986-1987 and compared with the concentrations found in big, healthy-looking trees. The results are presented and their significance discussed.

\section{Materials and methods}

Cloned spruces were used for all the experiments, either 4-year-old grafts or 6-year-old cuttings in 12-1 pots with standard soil mixture. They were exposed in the open-air fumigation installation in Birmensdorf (Keller 1976). Three of four rows with five closed-top fumigation chambers each received charcoal-filtered air, the fourth unfiltered ambient air. One of the rows with filtered air was continuously supplied with $100 \mu \mathrm{g} / \mathrm{m}^{3}$ ozone, another with $200 \mu \mathrm{g} / \mathrm{m}^{3}$ ozone. The plants were distributed among the five chambers of each treatment. Ozone was produced by electrical discharge of pure oxygen by an ozone generator (Fischer Model 502) and recorded on a strip chart recorder. Three fumigation experiments were carried out: the first from October through December 1986 with ten grafts in filtered air and $200 \mu \mathrm{g} / \mathrm{m}^{3}$ ozone each; the second from midMay through September 1987 (the last sampling during the fumigation being at the end of August), with five plants in every treatment; and the third from October through December 1987 with the same number of plants and treatments as in summer 1987 . The monthly means of ozone concentrations in the ambient air were around $50 \mu \mathrm{g} / \mathrm{m}^{3}$ during summer and below $20 \mu \mathrm{g} / \mathrm{m}^{3}$ in autumn. The maximum 30 min mean was $170 \mu \mathrm{g} / \mathrm{m}^{3}$ in the summer 1987. More information about the local air quality during the fumigation periods can be found in Bleuler and Landolt (1988).

The first sampling took place before the beginning of the fumigation $(=$ week 0$)$ except for the current-year needles in summer, which were analysed as soon as they were fully expanded. The beginning of the fumigation is termed week 1 . The samples were always taken on the same day of the week during the same time period (between $7.55 \mathrm{a} . \mathrm{m}$. and 10. a.m.). As very little material was used, consecutive sampling did not harm the plants.

The samples of the big trees were taken from two spruce trees in the garden of the institute with branches that could be reached from the ground and from two levels of the crown of a tree at the study site Lägern, 


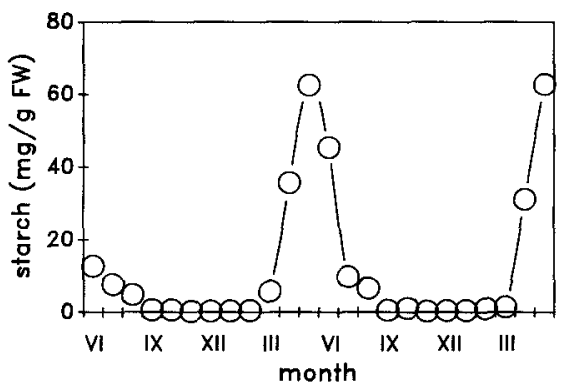

Fig. 1. Changes in starch in spruce needles during the first 2 years after bud-break. Six samples per needle age from three trees at two different locations were taken once a month over 2 years. Thus each circle represents the mean of 12 single measurements

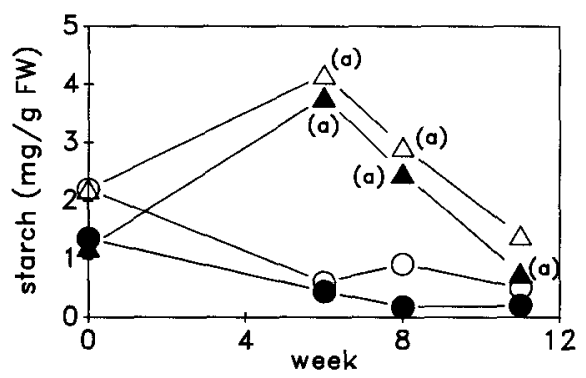

Fig. 2. Changes in the starch concentration in spruce needles during the fumigation experiment of autumn 1986. Each point represents the mean from the ten plants in the treatment (one sample per plant). Statistics were calculated using the test by ranks of Kruskal-Wallis. $(a)$ : Difference from the control at $P \leq 0.01$; $O$, filtered air (= control) current year needles; - filtered air 1-year-old needles; $\triangle 200 \mu \mathrm{g} / \mathrm{m}^{3}$ ozone current-year needles; $\Delta 200 \mu \mathrm{g} / \mathrm{m}^{3}$ ozone 1-year-old needles

where a scaffold had been built around one tree for other purposes. The two youngest needle ages were analysed once a month over 2 years.

For the determination of starch, $100 \mathrm{mg}$ of fresh needles from each plant was incubated with $1 \mathrm{ml} 80 \%$ ethanol in a water bath $\left(80^{\circ} \mathrm{C}\right)$ for $30 \mathrm{~min}$. The liquid was decanted and the needles were rinsed with $1 \mathrm{ml}$ $\mathrm{H}_{2} \mathrm{O}$. After homogenization with a Braun Microdismembrator the homogenate was twice extracted with $2 \mathrm{ml} \mathrm{H}_{2} \mathrm{O}$ and centrifuged ( $15 \mathrm{~min}$ $2500 \mathrm{~g}$ ). The supernatant was used for determination of sugars and cyclitols. To the sediment $1 \mathrm{ml}$ of $1 \mathrm{M} \mathrm{HC1O}_{4}$ was added and the mixture heated for $1.5 \mathrm{~h}$ at $60^{\circ} \mathrm{C}$, to dissolve the starch. Neutralization with $1 \mathrm{ml}$ $1 \mathrm{M} \mathrm{NaOH}$, buffering with $4 \mathrm{ml} 0.5 \mathrm{M}$ acetate $\mathrm{pH} 4.8$, and centrifugation $(15 \mathrm{~min} 2500 \mathrm{~g}$ ) followed. Starch concentration in the supernatant was first determined approximately by the reaction with iodine. A sample of $0-150 \mu \mathrm{g}$ starch was diluted to $3 \mathrm{ml}$ and $50 \mu \mathrm{I} / \mathrm{KI}(0.2 \% \mathrm{I}, 2 \% \mathrm{KI})$ was added. The absorbance at $536 \mathrm{~nm}$ was linear to the starch content. For a more reliable analysis the starch (maximum $30 \mu \mathrm{g} / 100 \mu \mathrm{l}$ ) was then digested to glucose with glucosidase from Aspergillus niger $(14 \mathrm{U}, 1 \mathrm{~h}$, $50^{\circ} \mathrm{C}$ ), and the glucose was measured enzymatically (test-combination by Boehringer).

\section{Results}

The starch content in the needles of the big spruces varied drastically with the changing seasons (Fig. 1). Even in June the fresh needles contained a considerable amount of starch, which decreased during the following months. In late autumn and winter almost no starch was detectable. In

\section{Summer}
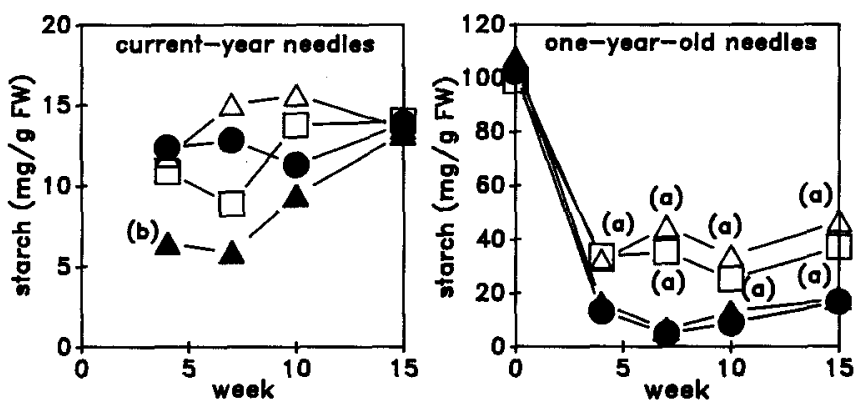

\section{Autumn}
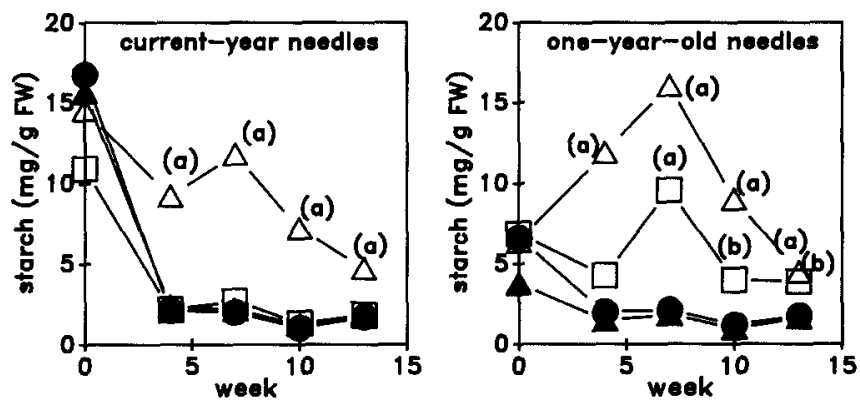

Fig. 3. Changes in the starch concentration in spruce needles during the fumigation experiment of summer and autumn 1987. Each point represents the mean from the five plants in the treatment (one sample per plant). Statistics were calculated using the test by ranks of KruskalWallis. Difference from the control at $(a): P \leq 0.01,(b): P \leq 0.05$. - filtered air (= control); $\boldsymbol{\Lambda}$, ambient air; $\square, 100 \mu \mathrm{g} / \mathrm{m}^{3}$ ozone; $\triangle, 200 \mu \mathrm{g} / \mathrm{m}^{3}$ ozone

the 1-year-old and 2-year-old needles large amount of starch accumulated in the chloroplasts before bud-break, reaching a maximum in early summer. As in the currentyear needles the amount decreased towards autumn.

Accordingly, when we started the first fumigation there was very little starch in the needles. The starch content still decreased a little in the control plants but rose in the fumigated needles during the first half of the experiment in both needle ages (Fig. 2). Afterwards it decreased again, and at the end of December the difference between the treatments was small.

In the two 1987 fumigations cuttings from a different clone were used instead of the grafts.

In summer the starch levels were generally high, as expected, and comparable with those found in the mature trees.

In the current-year needles no difference between the treatments was detectable and the amount of starch increased slightly during the fumigation. In the 1-year-old needles starch content decreased rapidly during the first 4 weeks, when the fresh needles were growing. This decrease was smaller in the ozone-fumigated plants but identical between ambient air and control (Fig. 3). After the fumigation the plants remained outside the chambers for 11 weeks, and at the end of December the starch content was determined once again (Table 1). There were no differences between the treatments any more. At the begin- 
Table 1. Starch content (mg/g fresh weight) in spruce needles after 19 weeks of fumigation and 11 weeks outside the fumigation chambers, at the end of December 1987

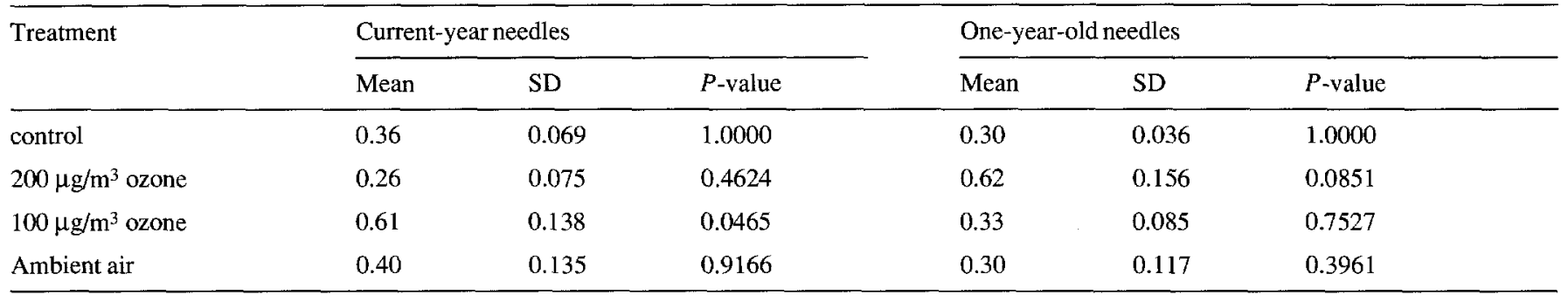

Statistics conceming the differences between the different treatments and the control plants were calculated using the test by ranks ( $n=5$ ) of Kruskal-Wallis

ning of the fumigation in autumn the starch content of the current-year needles decreased rapidly in all treatments except the fumigation with $200 \mu \mathrm{g} / \mathrm{m}^{3}$ ozone, where this decrease was much slower, resulting in significant differences. In the 1-year-old needles the results of the starch analysis were very similar to those from the previous year: an increase in the fumigated $\left(100\right.$ and $\left.200 \mu \mathrm{g} / \mathrm{m}^{3} \mathrm{O}_{3}\right)$ needles with a maximum in November followed by a reduction (Fig. 3).

In the middle of November 1986, when the differences between the treatments were at a maximum, samples were taken every morning and evening during 1 week to study the mechanism of starch accumulation more closely. Figure 4 shows that in the filtered air starch is accumulated in the needles during the day and translocated at night. In $200 \mu \mathrm{g} / \mathrm{m}^{3}$ ozone this mechanism is disturbed, resulting in a net increase of starch in the needles.

No signs of visible damage could be detected during the fumigations, but from January to March 1987 the plants which had been treated with $200 \mu \mathrm{g} / \mathrm{m}^{3}$ ozone, now standing in filtered air, lost more and more of the youngest needles. The 1-year-old needles from the fumigation with the higher ozone concentration in summer 1987 showed a slight chlorosis in the following winter. These effects were not due to frost.

\section{Discussion}

Ozone fumigation leads to an accumulation of starch in the chloroplasts of spruce needles. This effect was reproducible and was found in two different clones, in grafts as well as in cuttings, and in summer as well as in autumn.

In spruce needles starch is located exclusively in the chloroplasts (Esau 1969). Generally starch in chloroplasts is built up during daytime and translocated at night (Preiss and Levi 1979). It was shown that this translocation at night is disturbed in ozone-fumigated plants. This may be caused by an inhibition of the starch breakdown in the chloroplast or of the transport into the phloem where enzymes with sensitive sulphhydryl groups are found (Koziol et al. 1988).

The large seasonal fluctuations of the contents of starch in needles have been described before (Senser et al. 1971; Ericsson 1979). The intensity of the effect of ozone on starch in chloroplasts varies with these changes. The lower the starch concentration in the control plants, the more pronounced is this effect. When starch is built up as in the current-year needles in summer, there is no detectable effect; when the level is rapidly decreasing as in the 1-yearold needles in summer and the current-year needles in autumn, this decrease is diminished; and when the starch content of the needles is at a constant low level, as in the 1 -year-old needles in autumn, ozone even induces an increase.

Fink, who examined needles from our fumigations using histochemical methods, found some differences in the starch accumulation in the current-year needles during summer (personal communication). It is possible that small differences, which are not significant in a quantitative determination, can be seen in single cross-sections. There is a smaller difference in the current-year needles in summer than in autumn.

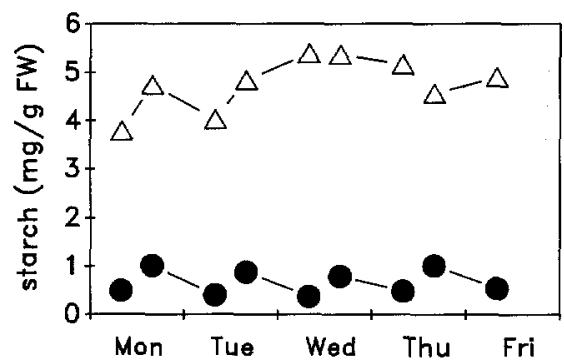

Fig. 4. Starch content in the current-year needles of spruce in the 6th week of the fumigation experiment in autumn 1986. Each value represents the mean of six plants (one sample per plant). Sampling took place daily at 8 a.m. and 4 p.m. . Filtered air; $\Delta, 200 \mu \mathrm{g} / \mathrm{m}^{3}$ ozone

Photobleaching because of the starch accumulation, as proposed by Osswald and Elstner (1985), is not likely, as the normal amount of starch in the chloroplasts in early summer is much greater than at any moment when an effect of ozone is detectable. There was some chlorosis in the fumigated needles after one fumigation, but it occurred when the starch effect had subsided and therefore must have another cause. As the absolute amount of accumulated starch is very small and the effect is only transient, it cannot have a great influence on assimilate partitioning.

Thus starch accumulation does not seem to be a key process for damage in ozone-affected spruce trees.

Acknowledgements. This project was partially supported by the Swiss National Science Foundation (NFP $14^{+}$). 


\section{References}

Bleuler P, Landolt W (1988) Luftbelastung 1987 im Raume Birmensdorf. Schweiz Z Forstwes 139: 631-636

Broshot NE, Tinnin RO (1986) The effect of dwarf mistletoe on starch concentrations in the twigs and needles of lodgepole pine. Can J For Res 16: 658-660

Ericsson A (1979) Effects of fertilisation and irrigation on the seasonal changes of carbohydrate reserves in different age-classes of needle on 20-year-old Scots pine trees (Pinus sylvestris). Physiol Plant 45: $270-280$

Esau K (1969) Pflanzenanatomie. Fischer, Stuttgart

Fink S, Braun HJ (1978) Zur epidemischen Erkrankung der Weisstanne Abies alba Mill. („Tannensterben“) I. Untersuchungen zur Symptomatik und Formulierung einer Virus-Hypothese. Allg Forst- Jagdztg 149: $145-150$

Hanson GP, Stewart WS (1979) Photochemical oxidants: effect on starch hydrolysis in leaves. Science 168: $1223-1224$

Keller T (1976) Auswirkungen niedriger $\mathrm{SO}_{2}$-Konzentrationen auf junge Fichten. Schweiz Z Forstwes 127: 237-251

Koziol HJ, Whatley FR, Shelvey JD (1988) An integrated view of the effects of gaseous air pollutants on plant carbohydrate metabolism. In: Schulte-Hostede (ed) Air pollutants and plant metabolism. Elsevier, Applied Science Publishers LTF London New York, pp $148-168$
Landolt W, Pfenninger I, Lüthy-Krause B (1989) The effect of ozone and season on the pool sizes of cyclitols in Scots pine (Pinus sylvestris). Trees 3: $85-88$

MacDonald PW, Strobel GA (1970) Adenosine diphosphate-glucose pyrophosphorylase control of starch accumulation in rust-infected wheat leaves. Plant Physiol 46: 126-135

Osswald W, Elstner EF (1985) Rezentes Fichtensterben in sogenannten Reinluftgebieten. GIT Fachz Lab 5: 400-410

Preiss J, Levi C (1979) Metabolism of starch in leaves C: starch degradation. Enz Plant Physiol 6: 282-312

Prinz B, Krause GHM, Jung KD (1985) Untersuchungen der LIS Essen zur Problematik der Waldschäden. In: Kortzfleisch $\mathrm{G}$ von (ed) Waldschäden Theorie und Praxis auf der Suche nach Antworten. Oldenburg, München Wien, pp 143-194

Samarakoon AB, Rauser WE (1979) Carbohydrate levels and photoassimilate export from leaves of Phaseolus vulgaris exposed to excess cobalt, nickel, and zinc. Plant Physiol 63: 1165-1169

Senser M, Dittrich P, Kandler O, Thanbichler A, Kuhn B (1971) Isotopenstudien über den Einfluß der Jahreszeiten auf den Oligosaccharidumsatz bei Coniferen. Ber Dtsch Bot Ges 84: 445-455

Tingey DT, Wilhour RG, Standley C (1976) The effect of chronic ozone exposures on the metabolite content of Ponderosa pine seedlings. For Sci 22: $234-241$ 